\title{
Prevalence and correlates of HIV and hepatitis B virus coinfection in Northern Alberta
}

\author{
Carmen Pittman $\mathrm{MD}^{1}$, Sabrina Plitt PhD ${ }^{1}$, Ted Birse $\mathrm{NP}^{2}$, Karen Doucette MD MSc ${ }^{1,2}$, Barbara Romanowski $\mathrm{MD}^{1,2}$, \\ Ryan Cooper $\mathrm{MD}^{1,2}$, Stan Houston $\mathrm{MD}^{1,2}$, Stephen Shafran $\mathrm{MD}^{1,2}$, Ameeta E Singh BMBS MSc ${ }^{1,2}$
}

C Pittman, S Plitt, T Birse, et al. Prevalence and correlates of HIV and hepatitis B virus coinfection in Northern Alberta. Can J Infect Dis Med Microbiol 2014;25(1):e8-e13.

BACKGROUND: HIV and hepatitis B virus (HBV) share transmission routes, and coinfection is associated with higher morbidity and mortality. To date, no Canadian studies have examined HIV-HBV coinfection.

OBJECTIVES: To examine the prevalence and correlates of HIV and HBV coinfections in Northern Alberta.

METHODS: The present study was a retrospective database review of all HIV-infected $(\mathrm{HIV}+)$ individuals in Northern Alberta from 1982 to 2010 and a chart review of HBV surface antigen-positive individuals for whom charts were available (46.2\%).

RESULTS: Of 2844 HIV+ patients, 2579 (90.7\%) had been tested for HBV surface antigen, and $143(5.5 \%)$ of these were HBV coinfected. Coinfected males were primarily Caucasian $(70.8 \%)$, and coinfected females were primarily black (56.4\%) or Aboriginal (31.3\%). Coinfected individuals were more likely to be male $(88.1 \%$ versus $71.3 \% ; \mathrm{P}<0.001)$ and to have died $(34.3 \%$ versus $17.9 \% ; \mathrm{P}<0.001)$.

CONCLUSIONS: The prevalence of coinfection with HBV in HIVinfected patients in Northern Alberta is lower than reported in other developed nations. The pattern of coinfections in Northern Alberta likely follows immigration trends. Recognition and management may be improving with time; however, further research and additional strategies are required to enhance the prevention, identification and management of HBV infection in HIV-infected individuals.

Key Words: Alberta; Canada; Coinfection; Hepatitis B; HIV

$\mathrm{H}^{\mathrm{N}}$ IV and hepatitis B virus (HBV) are major public health concerns. There are $>70,000$ Canadians living with HIV (1). Approximately 700 new HBV infections occur in Canada annually (2), and $>300$ million individuals are estimated to be diagnosed with HBV worldwide (3). Undiagnosed reservoir populations of both infections are believed to exist in Canada $(1,4)$.

Canada is a country of low endemicity for both HIV and HBV. While the prevalence of HIV is low in Canada overall, the incidence of infection is increasing among immigrants from endemic countries and men who have sex with men $(1,5)$. The prevalence of HBV declined with the introduction of universal childhood vaccination in 1995 (3). The population of individuals chronically infected with HBV in Canada is largely comprised of individuals from HBV-endemic countries in Asia and Africa, and also includes high rates in Aboriginal and high-risk lifestyle populations (2). Prevalence rates among these populations are comparable with those of endemic areas (4).

As a major centre for the oil industry, Northern Alberta has a unique population. There has been a recent, rapid population expansion, with population growth in Alberta being more than double the national average, in which international immigration is playing an increasing role (6).

\section{La prévalence et les corrélats de la co-infection par le VIH et le virus de l'hépatite B dans le nord de l'Alberta}

HISTORIQUE : Le VIH et le virus de l'hépatite B (VHB) partagent les mêmes voies de transmission, et la co-infection s'associe à un taux plus élevé de morbidité et de mortalité. Aucune étude canadienne ne porte sur la co-infection par le VIH et le VHB.

OBJECTIFS : Examiner la prévalence et les corrélats de la co-infection par le VIH et le VHB dans le nord de l'Alberta.

MÉTHODOLOGIE : La présente étude était une analyse rétrospective des bases de données de toutes les personnes infectées par le VIH $(\mathrm{VIH}+)$ dans le nord de l'Alberta entre 1982 et 2010 et une analyse des dossiers disponibles des personnes positives à l'antigène de surface du VHB (46,2\%).

RÉSULTATS : Sur les 2844 patients VIH+, 2579 (90,7\%) avaient subi un test de dépistage de l'antigène capsidique du VHB, et 143 (5,5 \%) étaient infectés par le VHB. Les hommes co-infectés étaient surtout de race blanche $(70,8 \%)$, et les femmes co-infectées, surtout noires (56,4 \%) ou autochtones (31,3\%). Les personnes co-infectées étaient plus susceptibles d'être de sexe masculin (88,1\% par rapport à 71,3\%; $\mathrm{P}<0,001$ ) et de mourir (34,3\% par rapport à 17,9\%; $\mathrm{P}<0,001)$.

CONCLUSIONS : La prévalence de co-infection par le VHB chez les patients du nord de l'Alberta infectés par le VIH est moins élevée que celle qui est déclarée dans d'autres pays industrialisés. Le mode de coinfection dans le nord de l'Alberta suit probablement les tendances d'immigration. Le dépistage et le traitement s'améliorent peut-être au fil du temps. Cependant, d'autres recherches et des stratégies supplémentaires s'imposent pour améliorer la prévention, le dépistage et le traitement de l'infection par le VHB chez les personnes infectées par le VIH.

HIV and HBV coinfection can occur due to shared routes of transmission (7). In areas of low HBV endemicity, such as North America and Western Europe, HIV and HBV coinfections occur primarily in immigrant populations and adult populations due to sexual and percutaneous transmission (7). The prevalence of chronic HBV coinfection among HIV-infected individuals in areas of low HBV endemicity has been reported to range from $6 \%$ to $14 \%$ $(8,9)$.

With the use of highly active antiretroviral therapy (HAART), HIV-infected individuals are living longer, and experiencing morbidity and mortality due to other causes. Coinfection with HBV is associated with increased mortality (10) and worse outcome (11) in HIV patients. HBV infections are more likely to be chronic $(12,13)$ and have higher infectivity $(14,15)$, and there is increased loss of HBV immunity in HIV-infected individuals $(16,17)$. Drug-induced toxicity may also play a role in liver disease (18). HIV can hasten the progression of HBV-related liver disease and/or cirrhosis (19,20). HIVinfected individuals with lower CD4 cell counts may also be at greater risk of developing hepatocellular carcinoma (21). Individuals coinfected with HIV-HBV are 17 times more likely to die of liverrelated causes compared with those monoinfected with HBV (22).

\footnotetext{
${ }^{1}$ University of Alberta; ${ }^{2}$ Northern Alberta HIV Program, Edmonton, Alberta

Correspondence: Ms Ameeta E Singh, University of Alberta, 3B20-11111 Jasper Avenue, Edmonton, Alberta T5K OL4.

Telephone 780-342-2300, fax 780-425-2194, e-mail ameeta@ualberta.ca
} 
Lamivudine was the only oral agent for antiviral treatment of HBV in Canada from its introduction in 1998 until 2006. While of modest efficacy, the utility of lamivudine is limited due to resistance rates of approximately $70 \%$ over four years (23), and it is no longer recommended as monotherapy (24-27). Current Canadian guidelines on the treatment of HIV-HBV coinfection recommend treatment with HAART regimens containing two drugs active against HBV (24). Drugs active against HBV currently used in Canada include interferons, lamivudine, adefovir, entecavir, telbivudine, tenofovir and emtricitabine $(24,28)$.

HIV-HBV coinfection is a public health concern with distinct management issues, and high morbidity and mortality. There are currently no Canadian studies on the prevalence, correlates and mortality of HIV-HBV coinfections. We conducted a retrospective review on a cohort of HIV-positive patients followed between 1982 and 2010 in Northern Alberta. Our objectives were to examine the prevalence of HIV-HBV coinfection and to describe the correlates associated with coinfection in this region.

\section{METHODS}

\section{Data sources}

The Northern Alberta HIV Program (NAP) Database was created in 2003 and contains information on all HIV-positive patients from a population of nearly two million individuals in Northern Alberta and parts of the Northwest Territories. All patients who test positive for HIV in this catchment area are referred to the NAP, and confirmed positive patients are entered into the database. The NAP database was created for clinical and research purposes, and has been used in several recent studies (29-31).

The NAP database is built on the Oracle platform and each patient file contains a unique identifier as well as demographic and selected clinical information. The NAP data are obtained from charts, laboratory results and Alberta NetCare electronic health records, and are entered by clerical staff. Data entry and modification is restricted by a user profile, and it is not double entered or checked. The data are updated after patient visits, with new laboratory results and when the NAP is made aware of changes in patient status. A database analyst ensures that the database is functional, runs database queries as requested and manages database fields.

Data for the present study were extracted from the NAP database inclusive of cases entered from the index case of HIV in Alberta in 1982 to May 2010. These data were used to identify patients who were reported as having tested hepatitis B surface antigen positive ( $\mathrm{HBs} \mathrm{Ag}+$ ). Information on sex, ethnicity, age, results and dates of microbiological testing, and risk factor information was extracted for both $\mathrm{HBsAg}+$ and $\mathrm{HBs} \mathrm{Ag}$-negative $(\mathrm{HBs} \mathrm{Ag}-)$ patients from the NAP database.

The four NAP clinical sites located in Edmonton (Alberta) were visited and available charts of coinfected patients were reviewed for further information. Every attempt was made to locate all records, including from potential storage locations. Both medications and dates were recorded for HAART regimens and information was based on chart notes, prescription records and medication profiles. Laboratory investigation results specific to HBV infection and HBV-related liver disease were also recorded based on chart notes and hard-copy laboratory results filed in the chart.

\section{Testing methods}

All microbiological testing was performed at the Provincial Laboratory for Public Health (Edmonton and Calgary, Alberta), and analyzed and reported as per their protocols. Testing methodologies have changed over time; however, all HIV screening during this time period was conducted with an enzyme immunoassay (EIA). All screen-positive tests were followed by a second EIA and confirmation by Western blot.

HBsAg testing involved EIA screening followed by a confirmatory EIA. Other hepatitis B serology, including hepatitis B surface antibody, hepatitis B core antibody (anti-HBc), hepatitis B e antigen ( $\mathrm{HBe} A g)$, and antibody to $\mathrm{HBeAg}$, were tested using a single EIA. HBV DNA samples were analyzed using quantitative DNA polymerase chain reaction (PCR) and were available in Alberta from December 2003.

Hepatitis $\mathrm{C}$ virus (HCV) PCR samples were analyzed using qualitative RNA PCR. HCV antibody testing began in 1992; methods have varied during this time span, but involve EIA for screening and confirmation with or without a third EIA or immunoblot test.

\section{Statistical analysis}

Variables were compared between $\mathrm{HBsAg}+$ and $\mathrm{HBsAg}-$ individuals using $\chi^{2}$ or Fisher exact tests for categorical variables and MannWhitney tests for continuous variables. Multivariable logistic regression was used to identify independent demographic and risk factor correlates for $\mathrm{HBsAg}$ positivity and assess the impact of possible confounders such as age at HIV and HCV diagnosis. Any variables identified by univariate analysis to be associated with HBV infection at a significance level of $\leq 0.10$ were included in multivariable analyses, as well as any potential confounding variables. If inclusion of variables did not result in meaningful changes to the coefficients or model, variables were not included in the final model. Statistical analyses were performed using Stata version 10 (StataCorp, USA).

\section{Ethics}

Ethics approval for this project was obtained from the Health Research Ethics Board at the University of Alberta (Edmonton, Alberta).

\section{RESULTS}

Of 2844 HIV patients in the NAP as of May 2010, 265 (9.3\%) were of unknown $\mathrm{HBsAg}$ status. Of 2579 patients with $\mathrm{HBV}$ test results, 143 (5.5\%) were $\mathrm{HBsAg}+$.

Compared with individuals for whom $\mathrm{HBsAg}$ testing results were documented, the 265 patients with unknown HBsAg status had a significantly earlier year of HIV diagnosis (1992 [interquartile range (IQR) 1988 to 2000] versus 1999 [IQR 1993 to 2004]; $\mathrm{P}<0.0001$ ), were younger (median age 31 years [IQR 25 to 38 years] versus 34 years [IQR 28 to 41 years]; $\mathrm{P}=0.0001$ ), were more likely to have died ( $33.2 \%$ versus $18.8 \% ; \mathrm{P}<0.001$ ), had fewer years of life after their HIV diagnosis (three years [IQR one to five years] versus five years [IQR three to eight years]; $\mathrm{P}<0.0001)$, and were more likely to be Caucasian $(64.0 \%$ versus $54.5 \%$; $\mathrm{P}=0.003)$ and less likely to be black ( $8.4 \%$ versus $14.5 \% ; \mathrm{P}=0.007)$.

There were no statistically significant differences in age at time of HIV diagnosis, age at death and years of life after HIV diagnosis between the $\mathrm{HBsAg}+$ and $\mathrm{HBs} \mathrm{Ag}-$ groups (Table 1). In univariate analyses, the $\mathrm{HBs} \mathrm{Ag}+$ group was significantly more likely to have an earlier median date of HIV diagnosis (1996 [IQR 1989 to 2001] versus 1999 [IQR 1993 to 2004]; $\mathrm{P}<0.0001)$, be male $(88.1 \%$ versus $71.3 \%$; $\mathrm{P}<0.001)$, more likely to have died $(34.3 \%$ versus $17.9 \% ; \mathrm{P}<0.001)$ and less likely to be Aboriginal (14.0\% versus $27.7 \% ; \mathrm{P}=0.0006)$. $\mathrm{HBs} A g+$ patients were less likely to be viremic with $\mathrm{HCV}(15.8 \%$ versus $63.7 \% ; \mathrm{P}=0.002)$ despite comparable anti-HCV seropositivity rates $(37.0 \%$ versus $40.0 \% ; \mathrm{P}=0.6)$. No differences were observed in serological results for cytomegalovirus, toxoplasmosis, varicella zoster virus and syphilis between $\mathrm{HBs} \mathrm{Ag}+$ and $\mathrm{HBsAg}-$ groups (data not shown).

The prevalence of HBV coinfection decreased with year of HIV detection; patients with HIV infection identified between 1982 and 1987 had an HBsAg prevalence of $13.0 \%$, while those diagnosed after 1996 had a rate of $4.2 \%(\mathrm{P}<0.0001)$. Figure 1 presents the HIV cases tested for HBsAg according to year of HIV diagnosis and the proportion testing positive for HBsAg at any time until May 2010.

HBsAg prevalence among males was significantly higher than among females (6.8\% versus $2.4 \% ; \mathrm{P}=0.001$.) Among males, a significant correlate of HBV coinfection on univariate analysis was being a man who has sex with men $(\mathrm{OR}=1.50 ; \mathrm{P}=0.03$; Table 1$)$. Being a man who has sex with men did not remain significant in multivariable analysis.

When patterns of ethnicity were examined, Caucasians represented the majority of coinfected male patients $(n=87$ [70.8\%]), followed by blacks $(n=16[13.0 \%])$ and Aboriginals $(n=15[12.2 \%])$. The 
TABLE 1

Demographics, mortality and select microbiological investigations among hepatitis B infected (hepatitis B surface antigenpositive) and noninfected (hepatitis B surface antigen-negative) HIV-positive individuals in Northern Alberta, 1982 to 2010 *

\begin{tabular}{|c|c|c|c|}
\hline \multirow[b]{2}{*}{ Demographic characteristic } & \multicolumn{2}{|c|}{ Hepatitis B virus surface antigen status } & \multirow[b]{2}{*}{$\mathbf{P} \ddagger$} \\
\hline & Positive $\left(n=143^{\dagger}\right)$ & Negative $\left(n=2436^{\dagger}\right)$ & \\
\hline Age at diagnosis, years & $32(28-40)$ & $34(28-41)$ & 0.2 \\
\hline Age at death, years & $41(35-48)$ & $49(33-48)$ & 0.8 \\
\hline Years of life after HIV diagnosis & $5(3-8)$ & $5(3-8)$ & 0.9 \\
\hline Year of HIV identification* & $1996(1989-2001)$ & $1999(1993-2004)$ & $<0.001$ \\
\hline Male sex, n (\%) & $126(88.1)$ & $1736(71.3)$ & $<0.001$ \\
\hline Deceased, n (\%) & $49(34.3)$ & $437(17.9)$ & $<0.001$ \\
\hline Incarceration, n (\%) & $26(19.3)$ & $504(24.4)$ & 0.2 \\
\hline \multicolumn{4}{|l|}{ Ethnicity, n (\%) } \\
\hline Caucasian & $88(61.5)$ & $1314(53.9)$ & 0.004 \\
\hline Aboriginal & $20(14.0)$ & $674(27.7)$ & \\
\hline Black & $25(17.5)$ & $351(14.4)$ & \\
\hline Other & $6(4.2)$ & $97(4.0)$ & \\
\hline \multicolumn{4}{|l|}{ Risk factors§, n (\%) } \\
\hline Needle stick & $0(0.0)$ & $11(0.45)$ & 1.0 \\
\hline Transfusion & $3(2.1)$ & $56(2.3)$ & 1.0 \\
\hline Vertical & $1(0.7)$ & $13(0.53)$ & 0.6 \\
\hline Bisexual & $20(14.0)$ & $245(10.1)$ & 0.1 \\
\hline Men who have sex with men (males only) & $75(59.5)$ & $859(49.5)$ & 0.03 \\
\hline Injection drug use & $39(27.3)$ & $833(34.2)$ & 0.09 \\
\hline Unknown & $3(2.1)$ & $23(0.94)$ & 0.2 \\
\hline \multicolumn{4}{|l|}{ Serology, n (\%) } \\
\hline Anti-hepatitis B surface antigen positive & $22(17.7)$ & $1167(50.4)$ & $<0.001$ \\
\hline Anti-hepatitis B core antibody negative & $6(9.8)$ & $773(61.6)$ & $<0.001$ \\
\hline Anti-hepatitis C virus positive & $37(37.0)$ & $801(40.0)$ & 0.6 \\
\hline Hepatitis C virus RNA positive & $3(15.8)$ & $261(63.7)$ & 0.002 \\
\hline Anti-hepatitis A virus positive & $43(70.4)$ & $1035(69.9)$ & 0.9 \\
\hline
\end{tabular}

Data presented as median (interquartile range) unless otherwise indicated. *Data collection ended in May 2010 ; ${ }^{\dagger}$ Denominators may not equal column totals due to missing data or serology testing not being performed; ${ }^{\ddagger}$ Calculated using Mann-Whitney test for continuous variables and $\chi^{2}$ or Fisher’s exact test for categorical variables; §Risk factor information is not mutually exclusive

majority of coinfected females were of black ethnicity (nine of 16 [56.2\%]), followed by Aboriginal ethnicity ( $n=5$ [31.3\%]). Except for one patient, all black females were from HIV-endemic countries, as defined by the Public Health Agency of Canada for surveillance purposes (32). Black ethnicity was highly associated with HBV infection in females (56.2\% versus $25.1 \%$; $\mathrm{P}<0.01)$.

In multivariable analyses, factors identified as independent correlates of $\mathrm{HBs} \mathrm{Ag}+$ status in this HIV population were male sex (adjusted OR [aOR] 2.56 [95\% CI 1.43 to 4.56]), being deceased (aOR 1.84 [95\% CI 1.21 to 2.80]), earlier year of HIV detection (aOR 0.95 [95\% CI 0.93 to 0.98]) and black ethnicity (referent: Caucasian; aOR 2.22 [95\% CI 1.28 to 3.88$]$ ).

Charts were located for less than one-half $(n=66$ [46.2\%]) of $\mathrm{HBsAg}+$ patients. These patients had a later diagnosis of HIV infection (2000 versus 1991; $\mathrm{P}=0.0001)$, were less likely to have died $(21 \%$ versus $45 \%$; $\mathrm{P}=0.001$ ), were less likely to be male ( $81 \%$ versus $93.5 \%$; $\mathrm{P}=0.04)$ and were more likely to be of black ethnicity (31.8\% versus $5.5 \% ; \mathrm{P}=0.0001$ ) than the remaining $\mathrm{HBs} \mathrm{Ag}+$ patients for whom charts were not available.

HBV DNA levels were reported for 33 of 120 (27.5\%) HBsAg+ patients in the database and 32 of $58(55 \%)$ patients for whom charts were available, with 17 of 32 (53.1\%) having detectable HBV DNA (note that the cut off for detection varied over time). Anti-HBc results were reported for 61 of $143(42.7 \%) \mathrm{HBs} \mathrm{Ag}+$ patients in the database and in 47 of $66(71.2 \%)$ patient charts, with 44 of 47 (93.6\%) testing positive. $\mathrm{HBeAg}$ results were reported for 31 of 143 (21.6\%) HBsAg+ patients in the database and 30 of $66(45.5 \%)$ patient charts, with 19 of 30 (63.3\%) testing positive. HBV DNA testing was not routinely

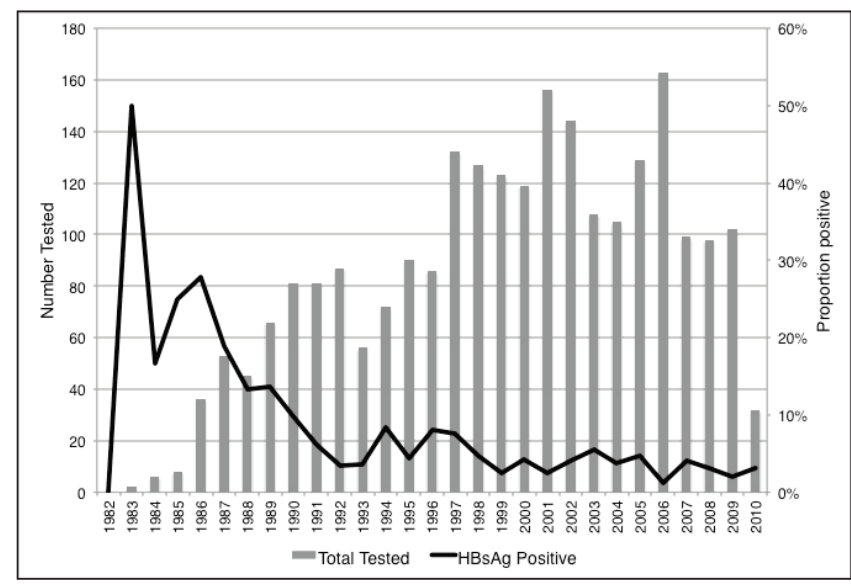

Figure 1) HIV patients tested for hepatitis B surface antigen ( $\mathrm{HBs} A g$ ) and proportion testing $\mathrm{HBs} \mathrm{Ag}$ positive according to year of HIV diagnosis, Northern Alberta, 1982 to 2010. HBsAg test result represents lifetime prevalence rates because testing could have occurred at any point until May 2010

available before that time, and denominators exclude patients who had died before December 2003. HIV diagnosis was made more than four weeks before HBV diagnosis in 41 of 66 patients (62.1\%), within four weeks of HIV diagnosis in nine of $66(13.6 \%)$ and more than four weeks after HBV diagnosis in six of 66 patients $(9.1 \%)$. 


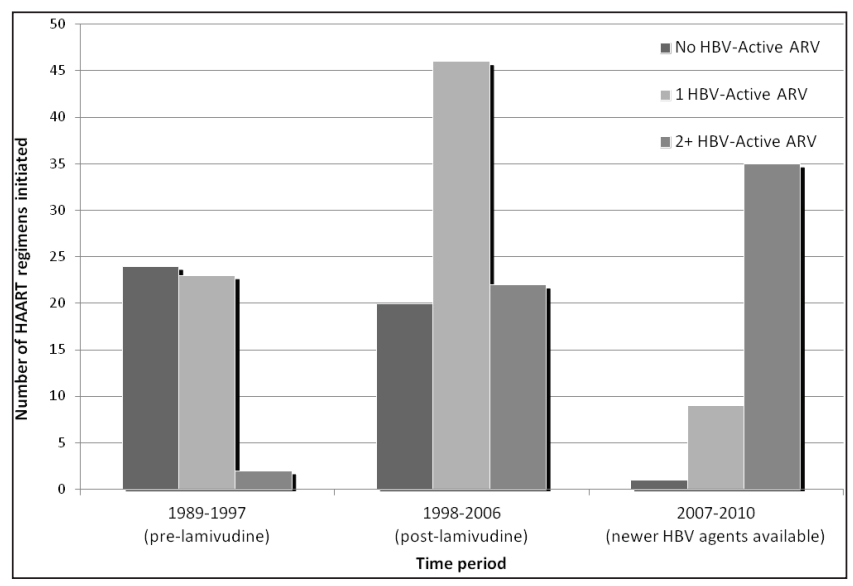

Figure 2) Number of patients receiving highly active antiretroviral therapy (HAART) regimens with no, one or two active hepatitis $B$ virus (HBV) agents (HBV-active antiretrovirals [ARV] include interferons, lamivudine, adefovir, entecavir, telbivudine, tenofovir and emtricitabine) according to time period in Northern Alberta, 1989 to 2010. Data collection ended in May 2010

For $\mathrm{HBs} \mathrm{Ag}+$ patients with available charts, the HAART regimen was divided into three time periods: 1989 to 1997 (prelamivudine); 1998 to 2006 (lamivudine available as of 1998); and 2006 to 2010 (newer HBV agents available) (Figure 2). From 1989 to 1997, the majority of HAART regimens initiated in coinfected patients did not contain any drugs active against HBV, although 23 HAART regimens were initiated in the cohort that contained lamivudine before its formal approval on the Canadian drug market, and two trial HAART regimens consisted of both lamivudine and tenofovir. After lamivudine was formally approved in 1998, the number of HAART regimens containing at least one HBV-active antiretroviral doubled. The number of regimens initiated containing at least two HBV-active antiretrovirals increased by almost 40\% after 2007 and, concurrently, the number of regimens containing only one HBV active drug decreased fivefold (Figure 2).

Liver ultrasound results were documented in 24 of $66 \mathrm{HBsAg}+$ patient charts, with 12 of 24 showing no abnormalities, four showing fatty infiltration, two showing hepatomegaly, two showing chronic hepatitis and/or fibrosis and four showing cirrhosis. Liver biopsy results were available in nine of $66 \mathrm{HBs} \mathrm{Ag}+$ patient charts, with one of nine having cirrhosis, one having acute drug-induced hepatitis, four having HBV-related liver disease (chronic hepatitis with fibrosis) and three having unrelated liver disease (granuloma, steatohepatitis).

\section{DISCUSSION}

We found a prevalence of HBV coinfection of $5.5 \%$ among a cohort of HIV infected individuals in Northern Alberta. This is lower than the coinfection rate of $6 \%$ to $14 \%$ previously reported in other areas of low endemicity for both HIV and HBV $(8,9)$ but higher than estimates of $0.1 \%$ to $0.5 \%$ prevalence of $\mathrm{HBV}$ infection in the general population in Canada $(2,4)$.

The majority of coinfected males were Caucasian, while coinfected females were more likely to be of black ethnicity. The strong association with black ethnicity in females may, in part, reflect demographic changes in Alberta's HIV-positive population. Women from HIV- and HBV-endemic countries in sub-Saharan Africa represent an increasing proportion of HIV cases in Alberta $(32,33)$. A recent large systematic review found an $\mathrm{HBs} A \mathrm{~g}$ prevalence of $15 \%$ among those both infected with HIV and from sub-Saharan Africa (34).

Limited access to HBV vaccination remains a significant problem in developing countries, although this is improving (35-37). As of the end of 2007, HBV vaccine had been introduced to 171 countries and an estimated $65 \%$ of the world's population, compared with 3\% in 1992 (38). Coverage is highest in the Americas at $88 \%$, while it is $69 \%$ in
Africa and 30\% in Southeast Asia (38). The decline in prevalence of HBV coinfection from $13.0 \%$ between 1982 and 1987 to $4.2 \%$ after 1996 may, in part, be attributed to the introduction of immunization programs in Canada. While the HBV vaccine is of limited use in individuals already infected with HIV due to poor immune response, completion of the vaccine series before HIV infection is an important strategy for preventing HBV coinfections $(39,40)$ and is best accomplished through universal vaccination at an early age. In addition, vaccination strategies for preventing HBV coinfection in HIV-infected individuals are being investigated, and benefits may be observed with alterations in vaccination dosing and scheduling (41-43).

Despite similar HCV seroprevalence among HIV patients with and without chronic HBV coinfection, we found that the rates of persistent HCV viremia were significantly higher among HIV patients without chronic HBV infection. Thus, chronic HCV infection appeared to be less likely in HIV patients also chronically infected with HBV. This pattern may reflect a 'viral interference' phenomenon whereby one viral infection may predominate in cases of dual- or triple-infected patients (44).

Seventy-five per cent of all deaths in both the HBV-infected and -noninfected groups occurred in those diagnosed with HIV infection before 1997. However, coinfected patients exhibited a higher proportion of death throughout the study period, particularly in the postHAART era, when HBsAg+ patients were more than two times more likely to die than those who were $\mathrm{HBsAg}-(23.5 \%$ versus $9.5 \%$; $\mathrm{P}<0.001)$. No conclusions on liver-related outcomes or causes of mortality can be made due to data limitations.

Data regarding HAART regimens was limited but suggestive of an increased use of two HBV active agents in our cohort after the introduction of the Canadian guidelines in 2007 (Figure 2). This may reflect greater adherence to guidelines for treatment of coinfections but may also reflect the recommendation in HIV treatment guidelines (27) to use Truvada (tenofovir/emtricitabine; Gilead Sciences Inc, USA) as the preferred backbone for HIV therapy in recent years. Analysis of differences in HAART regimens between HIV-HBV coinfected and HIV monoinfected groups was not possible with our data set and is an area for future research.

Our study had several limitations, including limited results of testing for $\mathrm{HBV}$ infection. Of our cohort, the $9.3 \%$ of patients of unknown $\mathrm{HBsAg}$ status were likely never tested for hepatitis B; therefore, unidentified coinfections may exist in our population. The very low overall rate of $\mathrm{HBeAg}$ and HBV DNA testing may reflect lack of documentation of these HBV markers in either the hard-copy charts (where available) or in the electronic database. These issues are similar to those reported in a Unites States study, which found that screening of HCV and HBV increased from $<20 \%$ to $>60 \%$ from 1998 to 2004 , but that screening and vaccination were not universally conducted or, if conducted, not documented despite care guidelines promoting screening and vaccination for HBV (45).

Due to the retrospective nature of the study and the method of data entry at the clinic, serial $\mathrm{HBs} \mathrm{Ag}+$ results were not available, thus making it impossible to definitively characterize the HBV infection as chronic based on a definition of persistent HBsAg positivity over a minimum six-month period. Although less likely, it is possible that some of the patients who tested HBsAg+ had acute infections that subsequently cleared. Correlation with liver enzyme results would have been helpful to further evaluate this possibility; however, limitations to the data preclude this. In addition, because anti-HBc testing results were inconsistently available, $\mathrm{HBs} \mathrm{Ag}-/ \mathrm{anti}-\mathrm{HBc}+$ individuals were not included in our cohort as coinfected individuals. Serial HBV test results and results of other coinfections (eg, hepatitis D) would also have allowed us to characterize the infectivity of HBV in our population, and to control for potential confounders. The retrospective nature of our study also precluded estimation of HBV incidence rates; this is a potential area for future study.

We were unable to evaluate outcomes, such as complications (eg, cirrhosis) or causes of death, due to limited information in the NAP 
database and available charts. Patients whose charts were reviewed represented a later cohort of HIV-HBV infected patients and, thus, our observations on the treatment and management of these patients may not be generalizable to the entire cohort of coinfected patients in Alberta.

\section{CONCLUSION}

Our data reveal a prevalence of $5.5 \%$ of HBV coinfection in Northern Alberta HIV-infected patients, slightly lower than that reported in HIV-infected populations in other developed countries but significantly higher than rates reported in the general population in Canada. Coinfected persons were more likely to be male, and more likely to be deceased. The majority of coinfected males were Caucasian, while coinfected females were more likely to be of black ethnicity, many of whom were from HIV-endemic countries. While our observations suggest that both HBV-specific laboratory testing and treatment improved with time, it also showed a need for enhanced patient follow-up and treatment for HBV in accordance with national guidelines as well as further research regarding the outcomes of HIV-HBV coinfections.

ACKNOWLEDGEMENTS: The authors acknowledge the invaluable assistance of the staff in the Northern Alberta Program and Edmonton STI Clinic for their assistance with obtaining records. Additionally, funding from the David and Beatrice Reidford Research scholarship was greatly appreciated.

DISCLOSURES: CP, SP, SH, TB and RC declare no conflicts of interest. KD has received speaker honoraria from Gilead and research support from Roche and Merck. BR has received speaker honoraria and research support from Merck and GlaxoSmithKline. SS has received research support from Abbott, Boehringer Ingelheim, Bristol Myers Squibb, Gilead, Merck, Pfizer, Roche and Vertex. AES has received speaker and moderator honoraria from Abbott Canada and Bristol-Myers Squibb Canada. The data contained in this article were presented as an oral presentation at the 20th Annual Canadian Conference on HIV/AIDS Research in Toronto, Ontario, April 14 to 17, 2011.

\section{REFERENCES}

1. Public Health Agency of Canada. Summary: Estimates of HIV Prevalence and Incidence in Canada, 2011. 2012. <www.phac-aspc. gc.ca/aids-sida/publication/index-eng.php\#er $>$ (Accessed September 5, 2013)

2. Hepatitis B in Canada.Viral Hepatitis and Emerging Bloodborne Pathogens in Canada. Canada Communicable Disease Report 2001;27(S3):10-12. < www.collectionscanada.gc.ca/ webarchives/20071222042310/http://www.phac-aspc.gc.ca/publicat/ ccdr-rmtc/01pdf/27s3e.pdf> (Accessed September 6, 2013).

3. Public Health Agency of Canada. Canadian Immunization Guide:Hepatitis B Vaccine. <www.phac-aspc.gc.ca/publicat/cig-gci/ p04-hepb-eng.php> (Accessed September 6, 2013)

4. Minuk GY, Uhanova J. Chronic hepatitis B infection in Canada. Can J Infect Dis 2001;12:351-6.

5. Hall HI, Geduld J, Boulos D, et al. Epidemiology of HIV in the United States and Canada: Current status and ongoing challenges. J Acquir Immune Defic Syndr 2009;1:51(Suppl 1):S13-20.

6. Martel L, Caron-Malenfant E. 2006 Census: Portrait of the Canadian Population in 2006, by Age and Sex: Findings. Alberta: the engine of population growth in the prairies. Demography Division, Statistics Canada. <www12.statcan.gc.ca/census-recensement/2006/as-sa/97551/index-eng.cfm > (Accessed September 5, 2013).

7. McGovern B. The epidemiology, natural history and prevention of hepatitis B: Implications of HIV coinfection. Antivir Ther 2007;12(Suppl 3):H3-13.

8. Alter M. Epidemiology of viral hepatitis and HIV co-infection. J Hepatol 2006;44(Suppl 1):S6-9.

9. Spradling P, Richardson J, Buchacz K, et al. Prevalence of chronic hepatitis $\mathrm{B}$ virus infection among patients in the HIV Outpatient Study 1997-2007. J Viral Hepatol 2010;17:879-86.

10. Nikolopoulos G, Paraskevis D, Hatzitheodorou E, et al. Impact of hepatits $B$ virus infection on the progression of AIDS and mortality in HIV-infected individuals: A cohort study and meta-analysis. Clin Infec Dis 2009;48:1763-71.

11. Chun H, Roediger M, Hullsiek K, et al. Hepatitis B virus coinfection negatively impacts HIV outcomes in HIV seroconverters. J Infec Dis 2012;205:185-93.

12. Bodsworth N, Cooper D, Donovan B. The influence of human immunodeficiency virus virus type 1 infection on the development of the hepatitis B carrier state. J Infec Dis 1991;163:1138-40.

13. Hadler S, Judson F, O'Malley P, et al. Outcome of hepatitis B virus infection in homosexual men and its relation to prior human immunodeficiency virus infection. J Infec Dis 1991;163:454-9.

14. Colin J, Cazals-Hatem D, Loriot M, et al. Influence of human immunodeficiency virus infection on chronic hepatitis B in homosexual men. Hepatology 1999;29:1306-10.

15. Gilson R, Hawkins A, Beecham M, et al. Interactions between HIV and hepatitis B virus in homosexual men: Effects on the natural history of infection. AIDS 1997;11:597-606.

16. Laukamm-Josten U, Muller O, Bienzie U, ldmeier H, Uy A, Guggenmoos-Holzmann I. Decline of naturally acquired antibodies to hepatitis B surface antigen in HIV-1 infected homosexual men. AIDS 1988;2:400-1.

17. Biggar R, Goedert J, Hoofnagle J. Accelerated loss of antibody to hepatitis B surface antigen among immnodeficient homosexual men infected with HIV. New Engl J Med 1987;316:630-1.

18. Sulkowski MS, Thomas DL, Chaisson RE, et al. Hepatotoxicity associated with antiretroviral therapy in adults infected with human immunodeficiency virus and the role of hepatitis $\mathrm{C}$ or $\mathrm{B}$ virus infection. JAMA 2000;283:74-80.

19. Ionnou GN, Bryson CL, Weiss NS, Miller R, Scott JD, Boyko EJ. The prevalence of cirrhosis and hepatocellular carcinoma in patients with human immunodeficiency virus infection. Hepatology 2013;57:249-57.

20. DiMartino V, Thevenot T, Boyer N, et al. Influence of HIV infection on the response to interferon therapy and the long term outcome of chronic hepatitis B. Gastroenterology 2002;123:1812-22.

21. Clifford G, Rickenbach M, Polesel J, et al. Influence of HIV-related immunodeficiency on the risk of hepatocellular carcinoma. AIDS 2008;22:2135-41.

22. Thio C, Seaberg E, Skolasky R, et al; Multicenter AIDS Cohort Study. HIV-1, hepatitis B virus, and risk of liver-related mortality in the Multicenter Cohort Study (MACS). Lancet 2002;360:1921-6.

23. Leung N, Lai CL, Chang TT, et al. Extended lamivudine treatment in patients with chronic hepatitis B enhances hepatitis B e antigen seroconversion rates: Results after three years of therapy. Hepatology 2001;33:1527-32.

24. Coffin CS, Fung SK, Ma MM. Management of chronic hepatitis B: Canadian Association for the Study of the Liver consensus guidelines. Can J Gastroenterol 2012;26:917-38.

25. Lok A, McMahon B. Chronic hepatitis B: Update 2009. Hepatology 2009;50:661-2.

26. EASL clinical practice guidelines: Management of chronic hepatitis B virus infection. J Hepatol 2012;57:167-85.

27. Panel on Antiretroviral Guidelines for Adults and Adolescents. Guidelines for the use of antiretroviral agents in HIV-1-infected adults and adolescents. Department of Health and Human Services. $<$ http://aidsinfo.nih.gov/contentfiles/lvguidelines/ adultandadolescentgl.pdf $>$ (Accessed January 10, 2014).

28. Sherman M, Shafran S, Burak K, et al. Management of chronic hepatits B: Consensus guidelines. Can J Gastroenterol 2007;21(Suppl C):5C-24C.

29. Bowker SL, Soskoine CL, Houston SC, Newman SC, Jhangri GS. Human immunodeficiency virus (HIV) and hepatitis $\mathrm{C}$ virus (HCV) in a Northern Alberta population. Can J Public Health 2004;95:188-92.

30. Plitt SS, Mihalicz D, Singh AE, Jayaraman G, Houston S, Lee BE. Time to testing and accessing care among a population of newly diagnosed patients with HIV with a high proportion of Canadian Aboriginals, 1998-2003. AIDS Patient Care STDs 2009;23:93-9.

31. Hughes CA, Zuk D, Foisy M, Robinson J, Singh AE, Houston S. Prenatal screening and perinatal HIV transmission in Northern Alberta, 1999-2006. Am J Public Health 2009;99(Suppl 2):S412-6.

32. Public Health Agency of Canada. HIV/AIDS Epi Updates: HIV/ AIDS in Canada among people from countries where HIV is endemic, April 2012, Centre for Communicable Diseases and 
Infection Control, Public Health Agency of Canada, 2012. <www. canac.org/NetworkNews/HIV-Aids_EpiUpdates_Chapter13_EN. pdf $>$ (Accessed September 5, 2013).

33. Alberta Blood-borne Pathogens and Sexually Transmitted Infections Surveillance Working Group. Alberta blood-borne pathogens and sexually transmitted infections surveillance report 2008. Edmonton: Alberta Health and Wellness, 2008.

34. Barth R, Huijgen Q, Taljaard J, Hoepelman AI. Hepatitis B/C and HIV in sub-Saharan Africa: An association between highly prevalent infectious diseases. A systematic review and metaanalysis. Int J Infect Dis 2010;14:1024-31.

35. Aspinall E, Hawkins G, Fraser A, Hutchinson SJ, Goldberg D. Hepatitis $\mathrm{B}$ prevention, diagnosis, treatment and care: $\mathrm{A}$ review. Occup Med (Lond) 2011;61:531-40.

36. Romano L, Paladini S, Van Damme P, Zanetti AR. The worldwide impact of vaccination on the control and protection of viral hepatitis B. Dig Liver Dis 2011;43(Suppl 1):S2-7.

37. Kao J, Chen D. Global control of hepatitis B virus infection. Lancet Infect Dis 2002;2:395-403.

38. Te HS, Jensen DM. Epidemiology of hepatitis B and C viruses: A global overview. Clin Liver Dis 2010;14:1-21.

39. Landrum ML, Hullsiek KM, Chun HM. The timing of hepatitis B virus $(\mathrm{HBV})$ immunization relative to human immunodeficiency virus (HIV) diagnosis and the risk of HBV infection following HIV diagnosis. Am J Epidemiol 2001:173:84-93.

40. Lopes VB, Hassing RJ, de Vries-Sluiis TE, et al. Long-term response rates of successful hepatitis $B$ vaccination in HIV-infected patients. Vaccine 2013:31:1040-4

41. Ni JD, Xiong YZ, Wang XJ, Xiu LC. Does increased hepatitis B vaccination dose lead to a better immune response in HIV-infected patients than standard dose vaccination: A meta-analysis? Int J STD AIDS 2013;24:117-22.

42. Kim HN, Harrington RD, Crane HM, Dhanireddy S, Dellit TH, Spach DH. Hepatitis B vaccination in HIV-infected aults: Current evidence, recommendations and practical considerations. Int J STD AIDS 2009;20:595-600.

43. Cruciani M, Mengoli C, Serpelloni G, et al. Serologic response to hepatitis $\mathrm{B}$ vaccine with high dose and increasing number of injections in HIV infected adult patients. Vaccine 2009;27:17-22.

44. Soriano V, Barreiro P, Martin-Carbonero L, et al. Treatment of chronic hepatitis $\mathrm{B}$ or $\mathrm{C}$ in HIV-infected patients with dual viral hepatitis. J Infect Dis 2007;195:1181-3.

45. Buskin SE, Barash EA, Scott JD, Aboulafia DM, Wood RW. Hepatitis $\mathrm{B}$ and $\mathrm{C}$ infection and liver disease trends among human immunodeficiency virus-infected individuals. World J Gastroenterol 2011;17:1907-16. 


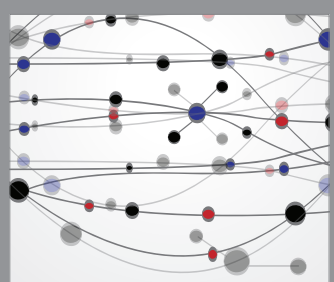

The Scientific World Journal
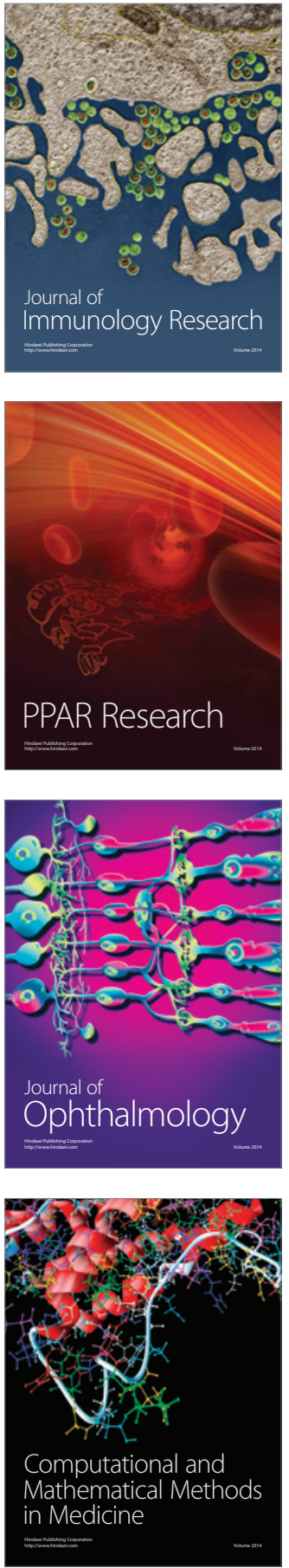

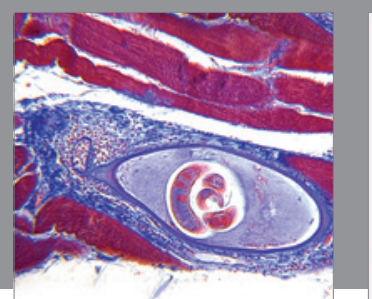

Gastroenterology Research and Practice

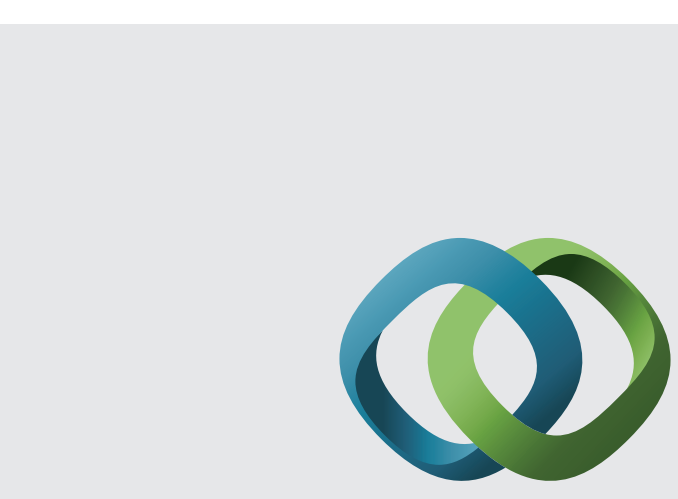

\section{Hindawi}

Submit your manuscripts at

http://www.hindawi.com
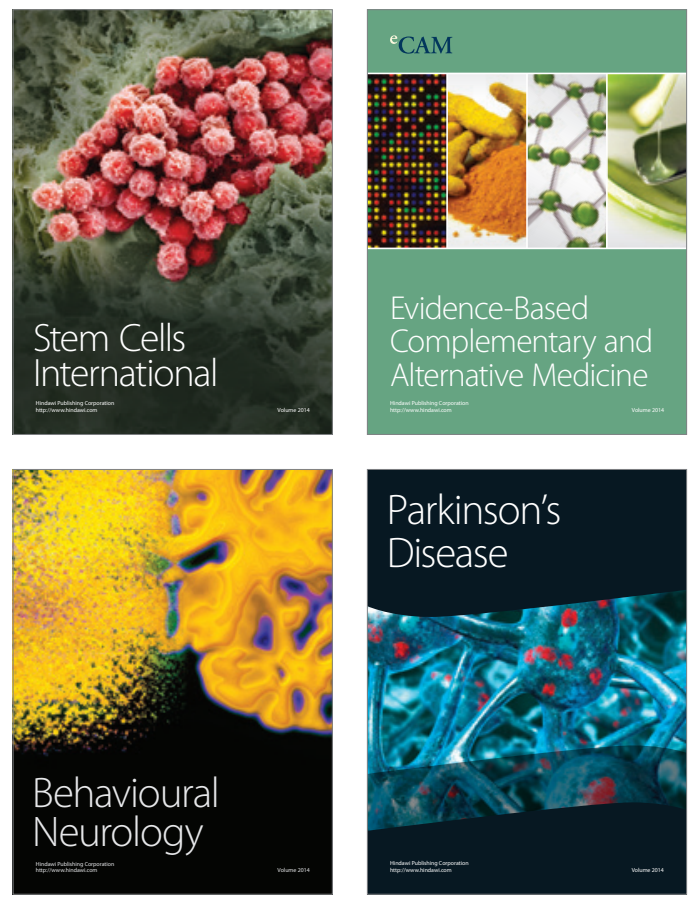
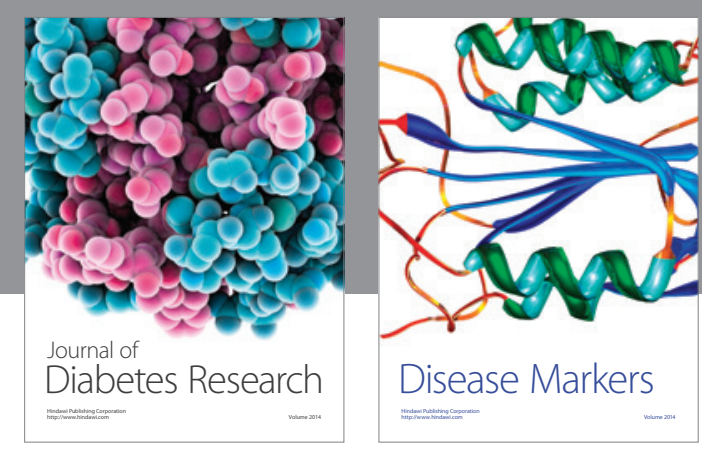

Disease Markers
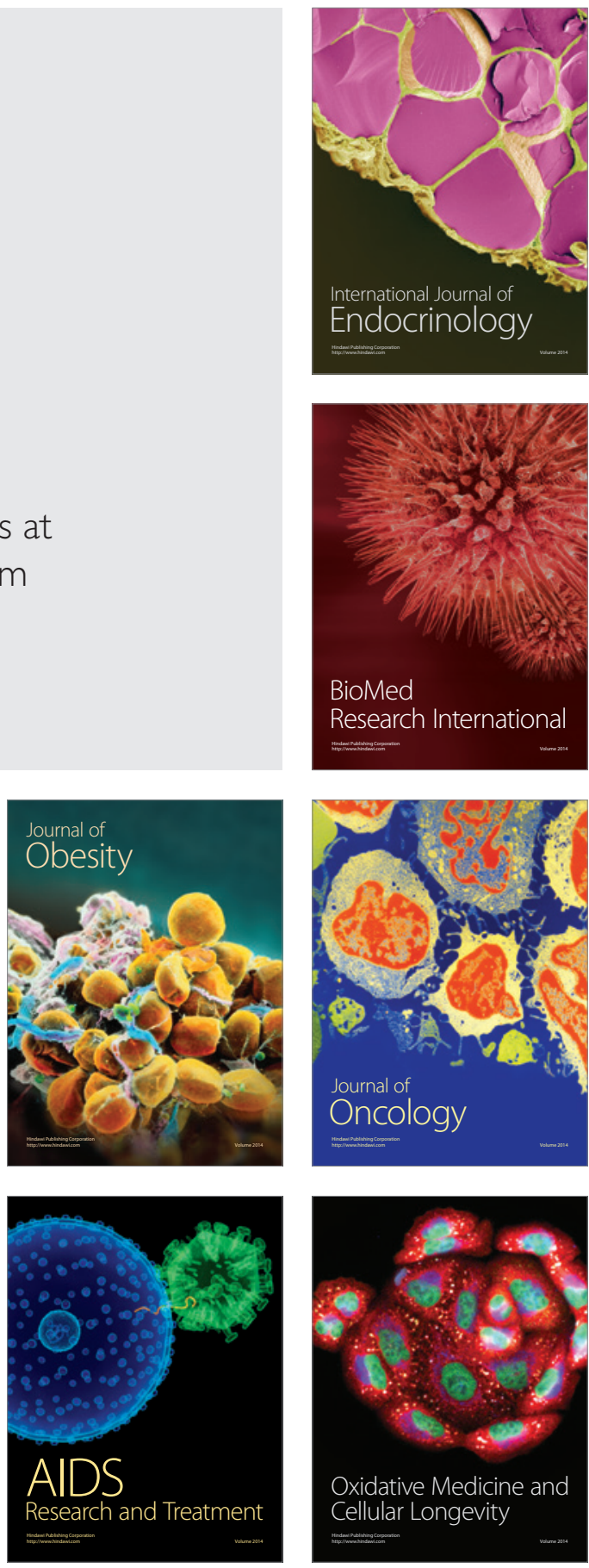